Forum Kritika: Regional Studies on the Chinese Diaspora

in the Philippines

\title{
RECONSTITUTING HISTORIES OF FILIPINO FAMILIES WITH CHINESE ANCESTRY: METHODOLOGY, SOURCES, AND RELEVANCE
}

\author{
Richard T. Chu \\ History Department, University of Massachusetts, Amherst
}

\begin{abstract}
Conducting one's family history can enrich not only one's own sense of self but also a nation's history, especially in a country like the Philippines where oligarchic families have historically had an impact on the nation's society, economy, and society. Many of these families are Tsinoy (Chinese-Filipino). Only few, however, have undertaken to reconstitute their histories. This essay discusses the various methods, sources, resources, and various frameworks (e.g., transnational, gendered) that one can use in the reconstitution of Tsinoy family histories. It also explains the significance that such family histories have in reframing and broadening our understanding of Philippine history.
\end{abstract}

\section{Keywords}

Chinese diaspora, Chinese in the Philippines; family history, genealogy, oral history, Tsinoy

\section{About the Author}

Richard T. Chu is Five College Associate Professor of History at the University of Massachusetts, Amherst. He has published several articles on the Chinese diaspora in the Philippines, and is the author of Chinese and Chinese Mestizos: Family, Identity, and Culture 1860s-1930s (Brill 2012; Anvil 2012) and Chinese Merchants of Binondo in the Nineteenth Century ( $U$ of Santo Tomas P 2010). He is currently working on his next book project that examines the racial discourses on the Chinese in the Philippines during the American colonial period. He teaches courses on Asian/Pacific/American history, Philippine history, and Chinese diasporic history. 
"YUNG LOLA KO INTSIK." ("My grandmother is Chinese.")

"Ah si Virginia Castro may lahing Intsik yan." ("Ah, that Virginia Castro has Chinese blood.")

"Ewan ko sabi nila may lahing Intsik kami kasi maputi ako at singkit." ("I don't know but they say I have Chinese blood because I am fair and have almond eyes.")

In my conversations with friends and acquaintances who are "Filipino," I have often heard of many claiming Chinese ancestry within their own families, or knowing of someone else who might have. The actual number of Filipinos today who indeed have Chinese ancestry is hard to ascertain, ${ }^{1}$ but it is not so difficult to meet individuals, especially those coming from prominent families or living in urbanized areas, who are of Chinese descent. But like so many families in the country, many have either forgotten or have vague memories of their histories. In recent years, however, a number of individuals with Chinese ancestry, whether they self-identify as "Filipinos," "Chinese," of "Tsinoy," have embarked on an oftentimes arduous but satisfying journey of reconstructing their family histories. This essay aims to provide some guidelines on how to go about doing the research, with the hope of encouraging readers to undertake their own Tsinoy family history projects.

\section{The Importance and Relevance of Reconstructing One's Family Tree}

If the book succeeds to awaken your consciousness of our past... and to rectify what has been falsified and slandered, then . . . we shall be able to study the future.

-José Rizal's “To the Filipinos” in his annotation of Sucesos de Las Islas Filipinas by Antonio de Morga (vii)

In this statement, Philippine national hero José Rizal makes the argument for looking back and rectifying-if need be-our history, in order to understand the future. On a societal and national level, examining the past can help unite a young country like the Philippines by giving it a sense of a shared past, and use this as a foundation to carve out a desired future. While history is oftentimes written from a macro-level perspective, it can also be viewed from the lens of microhistorical studies. In actuality, both types of histories are needed; both complement each other. Macro-level histories sometimes lack, or gloss over, the rich and complex details found in everyday life. Hence, microhistories such as family histories can alter, shape, challenge, or enrich histories written on a macro-level scale. However, microhistories, in order to have brevity, relevance, and breadth, need also to be studied within the broader context of macrohistory. ${ }^{3}$ 
In his study of early Southeast Asia, Wolters (18) points out that in this region's societies there is a lack of interest in preserving histories along lineage lines. Instead, focus has been given to stories of powerful individuals as a way to enhance these people's status vis-à-vis others. This may help explain why, compared to other countries such as China and the United States, the Philippines has not produced a rich collection of family histories, except from a few middle- to upper-class Filipino families. Even then, these family biographies or autobiographies are better termed as hagiographies, or are designed to enhance the reputation of these families or to legitimize their position of power in society. Such family histories lack a critical perspective that may be useful for understanding the way Philippine society works and can be changed (McCoy 1-10).

Moreover, the "Chinese" elements in these family histories, if there were, were often downplayed due to several reasons. ${ }^{4}$ One was the absence or the difficulty of obtaining available sources, especially if these were found in China. Another was the stigma attached to being "Chinese," especially when China became a Communist state in 1949. However, with former president Corazon Aquino recognizing and tracing her "Chinese" roots in 1988 when she visited her great-grandfather's native hometown Hongjian in Fujian Province, China, and with China's rise as a global power today, it is now acceptable, if not fashionable, to claim Chinese ancestry and to search for one's Chinese roots. ${ }^{5}$

On a personal level, learning about one's own family history can serve to enrich an individual's life in various ways. For instance, it can lead a person to appreciate the hardships and challenges that one's ancestors faced in providing for a better life for the family, and inspire him or her to work as hard. It can also broaden not only one's knowledge of one's own history but also of the wider world. ${ }^{6}$

As there have been more macro-level histories written about the Philippines, now is the time to focus on more micro-level histories, ranging from regional to local and to family histories. The relevance of the latter-particularly those that relate to Chinese families in the Philippines-to our broader understanding of our nation's history will be discussed at the end of this essay. In the next section, I will elaborate upon the methods and challenges of conducting such projects.

\section{Reconstituting Family Histories: Methods, Sources, and Challenges}

\section{Methods and Sources}

There are several ways to start reconstituting one's family history. The best way is to rely on oral history. ${ }^{7}$ After establishing from relatives or oral sources the existence of a Chinese ancestor, the next thing to do is to ascertain the name, especially the surname, of the ancestor. ${ }^{8}$ In the Philippine case, this is the complicated part, for many families bear a different surname from that of their ancestor. During the Spanish colonial times, the Catholic Church required conversion for any Chinese 
wishing to marry a local woman or run for public office. Upon baptism, the Chinese individual oftentimes acquired a Spanish name. It was common practice for the baptized to take the Spanish name belonging to his padrino (godfather). For instance, Tan Quin Lay, a prominent Chinese merchant, became also known as Carlos Palanca Tan Quin Lay, naming himself after his godfather who was a prominent Chinese merchant, Carlos Palanca Tan Quien-sien, who himself took his name from a Spanish colonel named Carlos Palanca. Tan Quin Lay was the founder of the La Tondeña Incorporada (Chu 302), but today he is better known by his Hispanicized name, Carlos Palanca, Sr. His descendants also use Palanca as their surname, and not Tan. ${ }^{9}$

During the American colonial period in the Philippines, two practices became commonplace that resulted in a person assuming a different name. In 1902, the American colonial government extended the Chinese Exclusion Act to the Philippines. The Act prohibited any Chinese male laborer, skilled or unskilled, from entering the Philippines. As a result, many either entered as "minor" children of legal residents of the Philippines or bought other people's Immigrant Certificate of Registration (ICR), especially of those who had decided to return to China permanently (Omohundro 17-8). These two practices consequently led to many Chinese Filipinos today who carry surnames assumed by their ancestors while entering the Philippines. Furthermore, during the Marcos era, when a presidential decree in 1974 allowed for the mass naturalization of long-term Chinese residents in the Philippines, many of those who opted for citizenship also decided to change their surnames so that these were more "Filipino" (Chu 409-10).

Hence, one of the first challenges of reconstructing one's family history is to find out not only whether one had a Chinese ancestor, but also what this ancestor's real Chinese name was or what names he or she had used. This step is crucial in facilitating one's research using textual sources.

\section{Textual Source Materials in the Philippines}

Textual sources are important components in the reconstruction of family histories. This section focuses on documents such as baptismal and marriage records, newspaper articles, books, and other materials that are available to the public. However, a caveat must first be given here about using public records. In general, wealthier people tend to leave more documents behind. For example, one can find numerous records pertaining to Carlos Palanca Tan Quien-sien, one of the most prominent Chinese in the latter part of the nineteenth century. In my research in different libraries and archives in Manila, his name and the names of other wealthy Chinese merchants such as Joaquin Barrera Limjap or Vicente Romano Sy Quia often appear. However, this should not discourage anyone from searching for materials pertaining to one's ancestors in the different repositories around the Philippines, for even less prominent individuals could leave some form 
of documentation behind. ${ }^{10}$ Below is a list of places where one could start looking for one's ancestors.

National Archives of the Philippines - With over 13 million Spanish documents and 60 million catalogued public documents, the National Archives of the Philippines (formerly Record Management and Archives Office) is the best place to start searching for one's ancestors, especially if one can trace the migration of one's ancestor to the Spanish or American colonial period. A good starting point would be to examine the set of documents known as the Protocolos or "Notarial Records." The Protocolos are bound volumes of contracts and instruments drawn up by different residents of Manila. Different notaries compiled these documents every year starting in 1866 . These documents consist of powers of attorney, sales of property and goods, testaments, issuance of promissory notes, marriage contracts, and many other forms of transactions. Other sets of archival documents that one can check to look for one's ancestors are the Padron General de Chinos (Chinese Tax Registers) and Registro de Central de Chinos (Central Register of the Chinese). The Padron is especially pertinent for those having roots in places outside of Manila, as registers were also created for the Chinese living as far north as Abra to as far south as Davao. For a general list of the Archives' holdings, see their website. However, it is better to visit the Archives personally as there are more specific indices, catalogues, and other guides to the materials found within. ${ }^{11}$

Archdiocesan Archives of Manila - The archives of the Archdiocese of Manila contain a vast collection of Spanish documents. Of these documents, those that would be of use to researchers are the Solicitudes de Chinos Sobre Bautismos (Baptismal Requests from Chinese), and the Informaciones Matrimoniales (Matrimonial Matters). The Solicitudes records cover the years 1774 to 1900. Each file found within this set of documents contains the letter of application of the Chinese; letters of recommendation from the parish priest, the Chinese gobernadorcillo ("little governor"), and notable or reputable members of the community; and the letter of approval from the archdiocese. The Informaciones records cover the years 1742 to 1927 . This set of documents pertains to marriage applications made before the Archdiocese of Manila and includes several applications from Chinese men to marry local (either indio or mestizo) women. Each file contains: the letters of application from each party; certifications of good moral conduct from the parish priest and eligibility status from witnesses; baptismal certificates of each party; as well as parental consent in case of minors. The documents in both sets of records may also contain the native place origins (in China or the Philippines) of the applicants, as well as the names of their parents. Hence, these records are very useful in tracing one's family history. However, according to the Archdiocesan Archives' website, the Informaciones are restricted records, and may require special dispensation from the Archdiocese to access these records (Archdiosecan Archives). ${ }^{12}$ Ruperto Santos, 
former curator and director of the Archdiocesan Museum, has also published a catalogue of the archdiocese's archival holdings.

It is not within the author's knowledge whether other archdioceses or dioceses throughout the Philippines have archives that might contain information on Chinese individuals. ${ }^{13}$ But whether one is from Manila or other parts of the Philippines, the Archives of the Archdiocese of Manila is still a good place to conduct research on one's ancestors. A good number of applicants for baptism and marriage came from other parts of Philippines. Given the itinerant lifestyle of many Chinese during the Spanish and American colonial periods, it was not unusual for them to be in Manila for both personal and economic reasons, and then return to the provinces. For instance, although Vicente Romano Sy Quia hailed from Vigan, he was often in Manila for business purposes. Hence, he left behind some records in the city, and was even buried at the Chinese cemetery in La Loma (Chu,306).

Chinben See Memorial Library, Kaisa Heritage Center - Named after Professor Chinben See whose dream was to create a center dedicated to the promotion of Chinese integration into Philippine society, the library has collected over 12,0oo titles in English, Chinese, and Filipino. It has the largest collection of both published and unpublished non-archival, along with some archival, materials pertaining to the Chinese in the Philippines. Aside from using books, theses, and other scholarly works, researchers can also peruse the yearbooks, annuals, and other types of "grey" literature. As Myra Sidharta defines it, "grey literature" refers to "printed publications that do not appear in the book-market" (85). Examples include annuals printed by organizations, institutions, or schools, and memoirs. The library also has other pertinent materials for family history research such as the set of microfilm reels containing photographs of Chinese tombstones found in cemeteries from around the country. Chinese tombstones often contain some biographical information about the deceased, including date of birth and death, birthplace, and names of the deceased's children. Another set of microfilm reels containing data found in Chinese clan and ancestral halls in the Philippines was produced through a joint project between Kaisa Para Sa Kaunlaran (the organization that runs the library) and the Institute of Modern History, Academia Sinica of Taiwan. ${ }^{14}$

Libraries - For other primary and secondary source materials, those conducting family history research should also visit the National Library; the Lopez Museum and Library; and the libraries of Ateneo de Manila University, University of the Philippines, and the University of Santo Tomas (UST). ${ }^{15}$ Such libraries, for instance, contain sources such as newspapers, magazines, theses, government documents, or books that may contain information or reports regarding certain individuals. It may be painstaking to have to go through these different materials, many of which are also in microfilm, but with perseverance and help from the library staff, one's research may produce rewarding discoveries.

The Spanish Archives of UST deserve special mention because it also contains the records kept by the Dominican priests who, along with the Jesuits, have since 
the early Spanish colonial period been involved in the evangelization of the Chinese in the Philippines. Among the materials found in the UST archives that would be of interest to family history researchers are the reports and materials pertaining to the Dominicans' Chinese ministry. ${ }^{16}$

"Chinese" Associations - Leaving their ancestral villages behind, sometimes for months, even years, many Chinese immigrants joined associations such as surname or hometown associations in order to obtain some form of support and aid, whether material or personal. These "Chinese" associations also collect genealogical information of their members, so a visit to their offices may yield valuable data. For example, the Philippine Charitable Association keeps a record of people buried at the Chinese cemetery (de la Cruz, Jr.). Other associations or organizations, such as the Federation of Filipino-Chinese Chambers of Commerce and Industry, Inc., as well as educational institutions such as Chiang Kai Shek College or Philippine Cultural High School, also publish annuals that may contain biographical information of their members or students, respectively. Such annuals, especially belonging to earlier years, are also found in the Chinben See Memorial Library.

\section{Other Types of Sources}

Wills and testaments are also possible sources. The National Archives of the Philippines holds documents classified as "Bienes de Difuntos" (Assets of the Deceased) and "Testamentos" (Testaments). One testament, for example, belonging to Lucio Isabelo Limpangco, contains biographical data about not only himself but also his two wives and different children (Chu 231). Furthermore, these documents may also contain information other than biographical data, such as family disputes or problems. For instance, when Sy Tiong-Tay apportioned his wealth among his five children, he deducted part of the inheritance of his oldest son Carlos because the latter had embezzled money from his father (Chu 235).

Other possible sources of information regarding one's ancestors are court cases, police reports, and other legal- and judicial-related documents. For those focusing on the Spanish colonial era, the National Archives would be a good place to start. In particular, one can resort to two sets of documents: the "Asuntos Criminales" (Criminal Matters) and the "Asunto Civiles" (Civil Matters). Like the testaments, these legal documents provide some biographical data on people involved in such cases, either as plaintiffs or defendants. For court cases in the twentieth century, one can consult the compendium of Philippine Supreme Court decisions found in law libraries or on the web (see, e.g., Lawphil Project).

In relation to the web, a typed entry in the Google search engine might also yield some results. There are websites such as GenForum or FamilySearch that might help one search for a particular ancestor. ${ }^{17}$ Some other sites, such as Facebook, 
Wikipedia, or personal blogs or web pages can sometimes yield information regarding certain individuals, families, or clans.

Apart from using oral histories and textual sources to reconstruct an individual's or family's history, there are "non-traditional" sources such as photographs, diaries, letters, notes, videos, and other "personal" items that can be found in one's (ancestral) home or in the possession of some family member or relative. Tomb inscriptions such as those found in the Manila Chinese Cemetery or La Loma Cemetery can also be useful in obtaining biographical data of one's ancestors.

\section{Materials Outside the Philippines}

Furthermore, if one has the time, money, skills, and determination, there are also sources outside the country that one could locate. For instance, the libraries of the Center for Asia-Pacific Area Studies and the Institute of Modern History in Academia Sinica contain materials (mostly in Chinese) that are not available in the Philippines. ${ }^{18}$ These sources include books written by Chinese scholars on the "Chinese overseas," and government publications such as gazetteers. ${ }^{19}$ Academia Sinica, through its Society for Overseas Chinese Studies, also publishes works related to the Chinese in the Philippines (See, "Research on the Chinese" 93-4).

Another valuable source is the Chinese family genealogy or zupu (族譜). These records mostly contain the names of male descendants of a particular lineage, along with some biographical information such as dates of birth and death; marriages; travels, etc. Occasionally, the names of wives or mothers would appear beside a person's name. The best way to start looking is to visit the hometown of a particular ancestor and determine whether such genealogy has been kept in the ancestral hall or residence. Otherwise, one can start by examining the different published catalogues of Chinese genealogical books to find out if his or her family's genealogy had been microfilmed, collected, or compiled and held in a particular repository (see Chia 513-4; Chao; Zhuang and Zheng).

Should one decide to visit the hometown of one's ancestor in China, the Federation of the Returned Overseas Chinese office might be able to arrange trips, meetings, and other visits. In every major city or town with a long history of emigration such as Xiamen, Jinjiang, and Quanzhou, the Federation has local offices.

When visiting hometowns, one might be able to find other valuable sources of biographical information. Stone inscriptions, for example, found in ancestral temples and describing the contributions of certain lineage members can provide details regarding one's ancestors (see Chia 514).

Finally, the libraries or archives in cities such as Seville, Madrid, Washington DC, Berkeley, London, Shanghai, Guangzhou, Singapore, Hong Kong, Taipei, and Beijing may also contain relevant material for one's family history research. As the Kaisa Para Sa Kaunlaran Inc. website reports, a researcher found documents 
in the British Foreign Office (presumably in London) "referring to letters of some prominent Chinese who sought British intervention and succor against the Spaniards" ("Cultural/Educational Activities"). The Library of Congress in Washington D.C. holds a copy of almost every major periodical published in both Western and non-Western languages, a number of which may not be found anywhere else in the world, such as some Chinese language newspapers from the Philippines that appeared early in the twentieth century but which were destroyed during the Japanese Occupation.

\section{Research Tools}

\section{General Reference Materials}

For a list of published works related to the topic of the Chinese in the Philippines, consult Chinben See and Teresita Ang See's Chinese in the Philippines: A Bibliography. The book contains an impressive list of various source materials, both primary and secondary, on the subject of the Chinese in the Philippines. See's "Recent Studies, Research, Publications and Source Materials on the Chinese in the Philippines" updates the bibliography by including works on the topic since $1990 .{ }^{20}$ The Huaqiao huaren baike quanguo shu (華僑華人百科全國書, Encyclopedia of Chinese Overseas), published in Beijing, also contains a section on academic works pertaining to the Chinese in the Philippines.

Before embarking on a family research project, one might want to read up on certain books to gain an overview-the "macro" side-of the history of the Chinese in the Philippines. For those interested in the period during the Spanish colonial period, Edgar Wickberg's Chinese in Philippine Life and Alfonso Felix Jr.s two-volume The Chinese in the Philippines are excellent resources. ${ }^{21}$ Andrew Wilson's Ambition and Identity and Richard Chu's Chinese and Chinese Mestizos provide historical information regarding the Chinese from the late Spanish colonial period to the early American colonial period. ${ }^{22}$ For books focusing specifically on the American colonial period, refer to Antonio Tan's The Chinese in the Philippines, 1898-1935 and Wong Kwok-chu's Chinese in the Philippine Economy. ${ }^{23}$ Continuing the historical narrative of the Chinese experience in the Philippines, specifically in the 194.0s, is Antonio Tan's The Chinese in the Philippines During the Japanese Occupation. ${ }^{24}$ For post-World War II, Teresita Ang See's various works, including the multi-volume The Chinese in the Philippines: Problems and Perspectives, are important sources. ${ }^{25}$ For those who read Chinese, Huang Zisheng and He Sibing's Feilubin huaqiao shi (菲律宾華僑史, The History of the Chinese in the Philippines) provides additional information not found in English-language sources. ${ }^{26}$

For a general history of an ancestor's birthplace, one can consult published gazetteers, such as the Jinjiang huaqiao zhi (晉江華僑志, Gazetteer of Overseas 
Chinese from Jinjiang) or the Quanzhou shi huaqiao zhi (泉州市華僑, Gazetteer of the City of Quanzhou).

The aforementioned list of reference materials is by no means exhaustive. Dissertations, book chapters, or published journal articles are also helpful. However, the materials presented in the previous paragraphs are generally more accessible, informative, and broad in scope.

\section{Biographies/Family Histories}

Rodrigo Lim's Who's Who in the Philippines (Chinese edition) contains short biographies of certain Chinese individuals. The Chinese-language gazetteers published by counties or cities such as the Xiamen huaqiao zhi (厦門華僑志, Gazetteer of Overseas Chinese from Xiamen) often have a section on important or famous individuals from their locales. Two other Chinese publications, Li Tianxi's Jinjiang huaqiao yishi (晉江華僑軼事, Anecdotes of Chinese Overseas from Jinjiang) and Zhou Nanjing's Shijie huaqiao huaren cidian (世界華僑華人詞 典, Dictionary of Overseas Chinese) also contain short biographies of Philippine Chinese.

A few books published by individuals on their family history could also provide models on how to go about conducting family history research. One good example is Cornelia Lichauco Fung's Beneath the Banyan Tree. It is an impressive work not only in its breadth of research involving the author's ancestry dating back to the Spanish colonial period--when her great-great grandfather Thomas Li Chau Co first came to the Philippines in the 1830s--but also in its rich use of various sources for the reconstitution of the Lichauco family. More importantly, her account veers away from the usual nation-centered accounts of family histories and demonstrates the transnational or cross-regional linkages that many of these families created, enriching and broadening not only her own family's history but also of what we may call "Philippine" history. ${ }^{27}$ Fung's work establishes a new template for family history-writing that differs from the frameworks of many Filipino family biographies, ${ }^{28}$ especially of the elites, that tend to focus on the "Filipino" and "Philippine" side of their histories. ${ }^{29}$

Other books, either in Chinese or English, can be found at the Chinben See Memorial Library, in other libraries, and even bookstores. But as mentioned earlier, these histories tend to be hagiographic. ${ }^{30}$

\section{Dictionaries}

For those needing a dictionary to translate Spanish sources, Gooch and de Paredes's Cassell's Spanish-English, English-Spanish Dictionary is a good dictionary, although there are many other good Spanish-English dictionaries available, whether in print or on the web. Another kind of dictionary that one might find useful is the 
Spanish paleographic dictionary. This dictionary can aid a researcher to decipher certain ways in which words or sentences were either abbreviated or truncated in earlier times. Finally, as these Spanish documents may contain words that may not be in use anymore, or were unique to the period in which one's ancestor lived, one might want to consult Wenceslao Retana's Diccionario de Filipinismos which contains certain local and foreign terms used in Philippine society during the Spanish and early American colonial periods that may not be in use today or anywhere else.

For Chinese documents, there are also many good modern Chinese-English dictionaries to choose from, but the Oxford version of $A$ Modern Chinese-English Dictionary (現代漢語詞典) is quite reliable. For classical Chinese, the Mathews Chinese-English dictionary is highly recommended. Moreover, since many names (e.g., personal or surnames, places) in archival documents were Romanized from their Hokkien (福建, Fujianese) derivatives, it would be helpful to have a pinyinHokkien dictionary. ${ }^{31}$ These dictionaries can either be purchased in local and foreign bookstores, or found electronically (e.g., 台語線頂字典, Taiwu xianding zidian).

In the reconstruction of family histories, it is also important to be familiar with the Chinese dating system. In many documents, such as genealogies or zupus, years that connote birth and death dates are often recorded in terms of the reign years of emperors (nian hao 年號) and the lunar calendar. Some Chinese dictionaries would contain a chart of these reign periods. Certain websites also provide a way to search for the Western (Gregorian) calendar equivalents of lunar dates. ${ }^{32}$

Finally, in the search for an ancestor's birthplace, one should note that in some instances, the name of a certain barangay, village, town, city, county, province, or prefecture might have changed. Furthermore, several small villages or towns may have the similar names. Hence, one should carefully ascertain the county or prefecture of an ancestor's birthplace. As mentioned earlier, for locating an ancestor's birthplace in China, the gazetteers are helpful references since they not only provide detailed maps but also the history of a certain locale.

\section{Research Assistants}

To hire professional researchers who can facilitate or assist with one's research, one can contact either Kaisa Para Sa Kaunlaran Inc.; the history departments of different universities; or the National Archives of the Philippines. These places might be able to recommend researchers who possess the necessary training and skills (such as translating foreign-language sources) to conduct family history research. The best researchers are those who also have some knowledge on the historical contexts of both the texts or the documents being used, and the period in which one's ancestor lived. 


\section{Research Challenges}

Apart from the pragmatic and logistical challenges of researching one's family history-such as where to look for sources or how to verify information, especially those taken from memory-there is that question of what to include or exclude in the reconstruction of one's family history. One may encounter some reluctance on the part of a family member to divulge details about an ancestor or a family "secret." One particular sensitive issue may pertain to family squabbles over inheritance; the existence of another family that one's own ancestor had; the shame of having an ancestor who was an adopted son or daughter, or born out of wedlock; or an ancestor's brush with the law. What one eventually decides to include or exclude from the family history largely rests on one's objectives and intended audience. As a historian, I try to approach such stories without attaching any moral judgment, but for non-historians or non-academics, it will be more difficult to simply include everything that they gather from sources, especially when these reveal some aspects of the ancestors' or families' lives that may not be so flattering.

\section{Example of Family History: My Own}

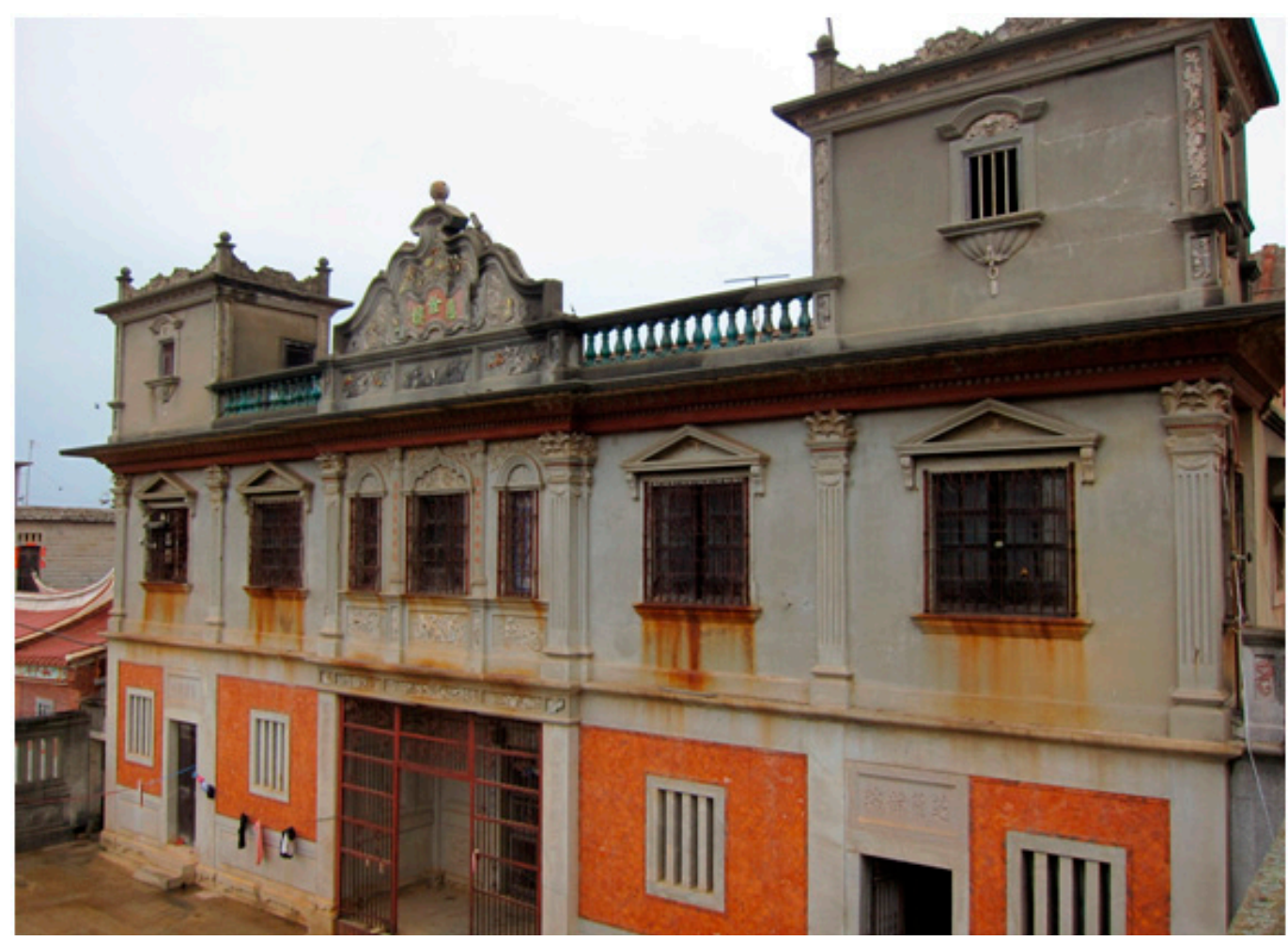

Fig. 1: House built by author's paternal great-grandfather Yuanda in the 1920s, located in Zengkeng, Jinjing, Fujian, China. 
At this point, I would like to share some of my research findings pertaining to my own family history. This family history project is a work-in-progress and therefore there are still gaps to fill. But I am sharing this piece of my family history in order to offer readers an example of what an individual may encounter as he or she undertakes research for one's "Chinese" roots.

In reconstituting my own family history, I discovered that, as far as records show, my "great-grandfather" Yuanda was the first paternal ancestor to come to the Philippines. I place "great-grandfather" in parenthesis because he is not biologically my great-grandfather. In searching for my "roots," I returned to my paternal lineage's ancestral village Zengkeng (曾坑), in the town of Jinjing (金井) and the county of Jinjiang (育江). ${ }^{33}$ In the three times that I have visited, I managed to find the zupu of the family, which is still being kept at the house that Yuanda built (see Fig. 1).

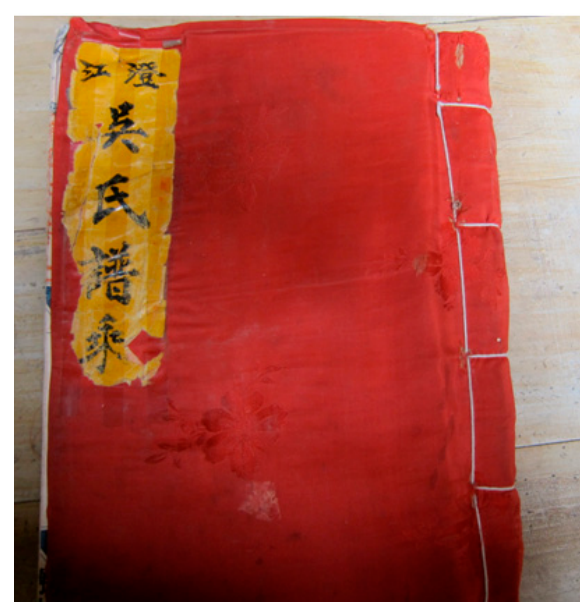

Fig. 2: The Wu of Zengkeng Genealogical Book.

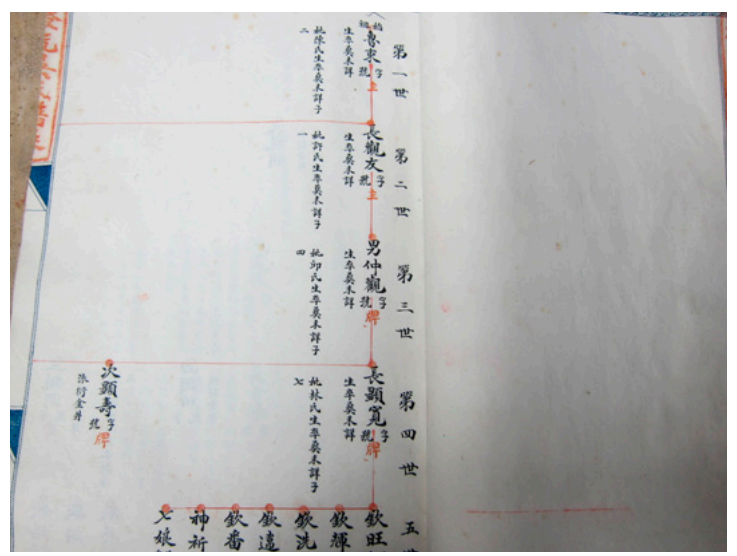

Fig. 3: Wu Surname Genealogy showing lineage of author from first ancestor Lu Dong (魯東), seventeen generations back.

According to the family genealogy Wushi jiapu (吳氏家譜), my biological greatgrandfather Yuanyuan (元緣) belongs to the fourteenth generation from the time of the first ancestor Lu Dong (魯東) listed in the genealogy (see Fig. 3). ${ }^{34}$ The second son of 13 th generation Kai Zhu (開艼), Yuanyuan was born on 5 September $1871 .^{35}$ His mother was the concubine listed as Jiu (酒). He married my great-grandmother (whom we called Tai-ma 太馬, literally "great-grandmother" in both Hokkien and Mandarin) (see Fig. 4) who was listed in the genealogy as having been born on 11 August 1878 . Hence, she was six years younger than my great-grandfather and was the daughter of a certain Chen Jiao (陳教) from a place called Fuquan (福全). 


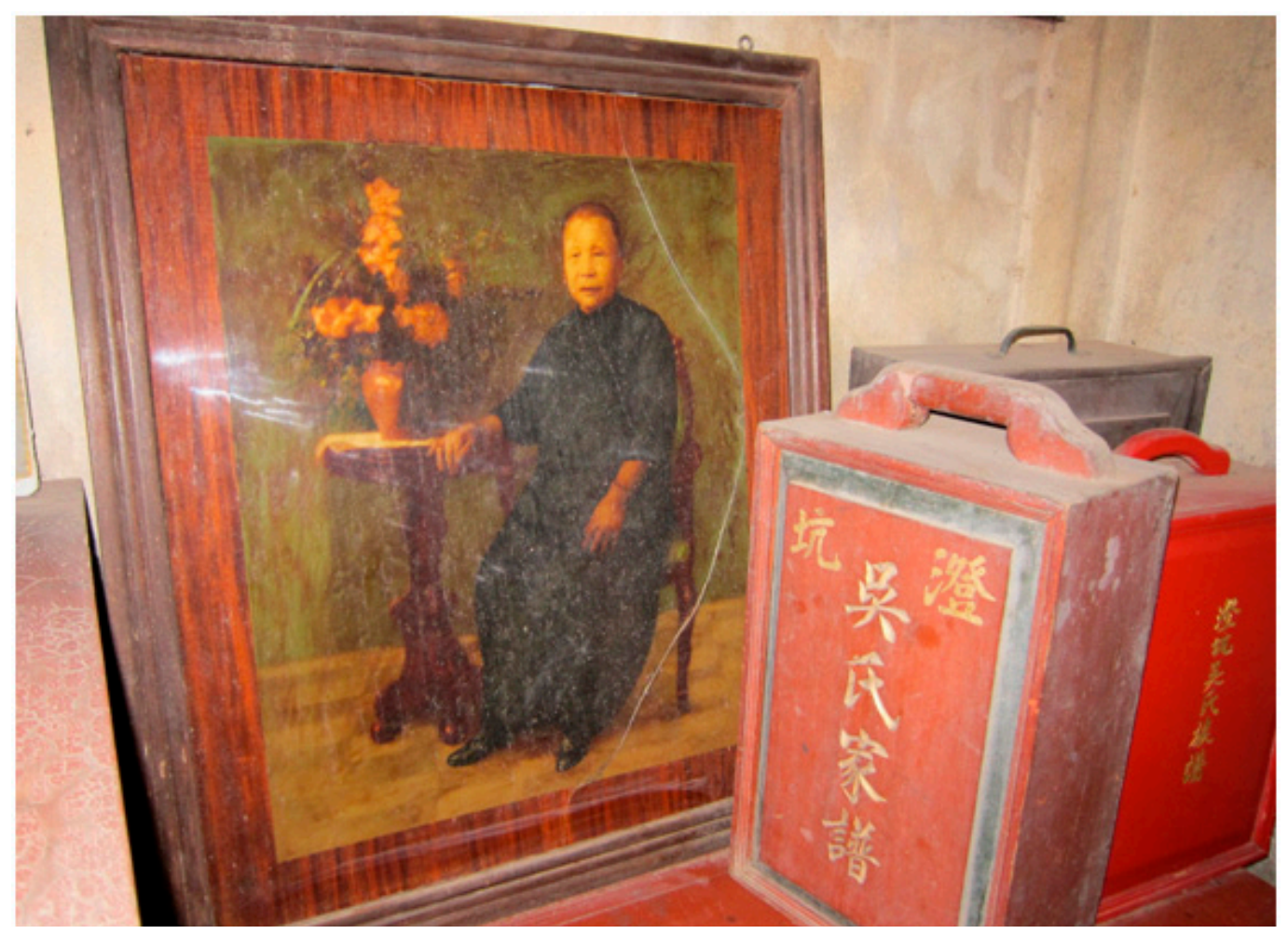

Fig. 4: Photo of author's great-grandmother and box containing Wu family genealogy.

The genealogy states that Yuanyuan settled in Taiwan. According to my second paternal aunt, Yuanyuan left China for Taiwan to work as a janitor for the grandfather of Go Tiong Tai, a family friend named (K. Tan). My great-grandmother was still pregnant with my grandfather, Bingsheng (秉侾), when Yuanyuan died on 30 May 1898, at the age of twenty-six. No one knew how he died, except that he had become ill. Whether he died and was buried in Taiwan is not clear. My greatgrandmother received the belongings of my great-grandfather, including a letter he wrote stating how his employers had maltreated him and accused him of stealing a gold ring. My great-grandmother used to tell this story

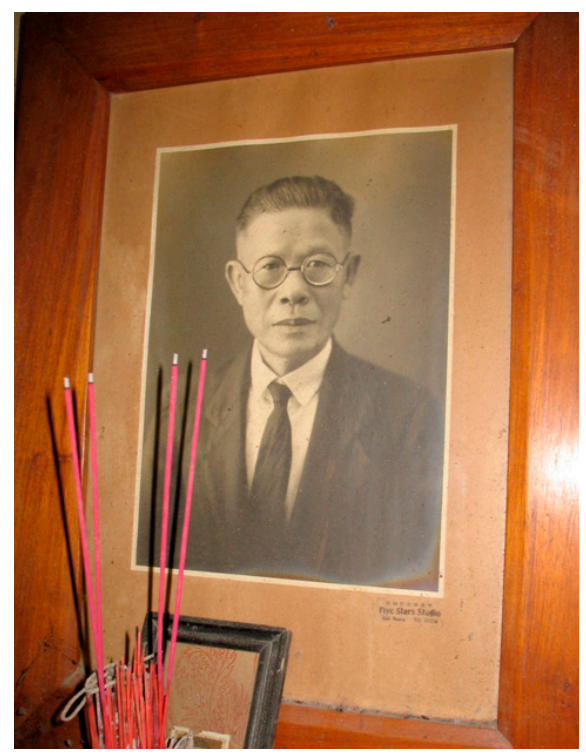

Fig. 5: Portrait of author's "greatgrandfather" Wu Yuanda. 
to her children, including my grandfather who became very emotional whenever he read his father's letter (K. Tan).

After he died, his younger brother Yuanda (元搭) became my "great-grandfather." Yuanda (see Fig. 5) was born two years after Yuanyuan, on 30 March 1873. Yuanda is hence listed as third in the genealogical line. Yuanda also had a different mother, a person surnamed Wang (王) and named He (鶴). Yuanda married the eldest daughter of Wang Guozhou (王國周). She was born 2 February $1883 .{ }^{36}$ However, she died young, on 29 May 1902, at the age of nineteen. ${ }^{37}$ As a result, my greatgrandmother, who was then a young widow, married Yuanda. With this marriage, my grandfather Bingsheng became Yuanda's adopted son and also listed at the first son of Yuanda's lineage. Bingsheng was followed by Yuanda's first biological son Binglin (秉麟), who was born on 12 December $1912 .{ }^{38}$ Binglin was followed by

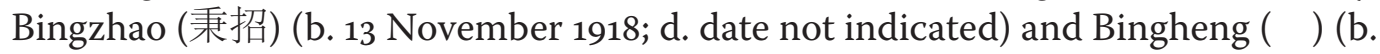
9 August 1920; d. date not indicated). Bingheng was the son of another deceased brother of Yuanda, and was adopted by Yuanda and my great-grandmother.

Yuanda left an account of his life in his testament. According to this document, his mother passed away when he was just six years old, and when he was twelve, in 1886, he traveled to Taiwan and lived there for over a year before returning home with his father $(\mathrm{Wu})$. He went into agriculture back in the village, but due to natural disasters and the barrenness of the soil, he decided to travel again.

I was seventeen years old [i.e., around early $1890 \mathrm{o}$ ], a time when transportation was inconvenient. I took a boat that was both simple and crudely made. Unfortunately, we were met by a heavy storm, and the little boat felt like a small grain of rice in the vast ocean. It's really hard to describe the true situation to those who didn't experience (what I did). The boat floated up and down, again and again, and it took one month to reach the Philippines. At the time the Spaniards ruled the country with tyranny. The people, unable to bear further suffering, proceeded to eradicate the tyrannical rule. $(\mathrm{Wu})$

He wrote in his testament that he witnessed the local revolutionary movement against Spain while at the same time observing how the Qing dynasty government, filled with corruption, did not have sufficient military power to protect their Chinese subjects in the Philippines, where "thousands of Chinese" died. He started to work as a carpenter, and after a while, the Tabacalera Company (沓描加例撈) hired him to work as a manager of their "department of architecture." He then sent some of his savings to a certain "Ganken" (甘肯) ${ }^{39}$ and started in Manila a plywood business named "Gotaco Plywood Corporation," which in Hokkien he called “Chìn bō" (振茂 zhenmao; “to flourish"). In time, the company prospered, and in 1929, he returned to China and built a house worth 100,000 pesos. Based on the introduction given by a certain Ming Feng (鳴鳳) who revised and updated the family tree, Yuanda also built the ancestral hall (see Fig. 6) in the summer of 
1933 (Ming). In 1937, he returned to Manila. When the Japanese invaded Manila in 1942, he had to close down his business, and flee to the city of Xiandaluo (仙 答洛; San Pablo, Laguna). His third son Bingzhao was injured in a Japanese plane attack and was hospitalized. His second son Binglin's "disease returned and he was so shocked by the sight of so many people injured with their legs and arms broken in the hospital that in the following year he died" (Wu). His plywood company was completely destroyed during the liberation of Manila. In time, he rebuilt the business and it prospered again. He bought land in Laolaonayinduan (撈掞那印段, could be Cabanatuan) and in Xiamen (K. Tan).

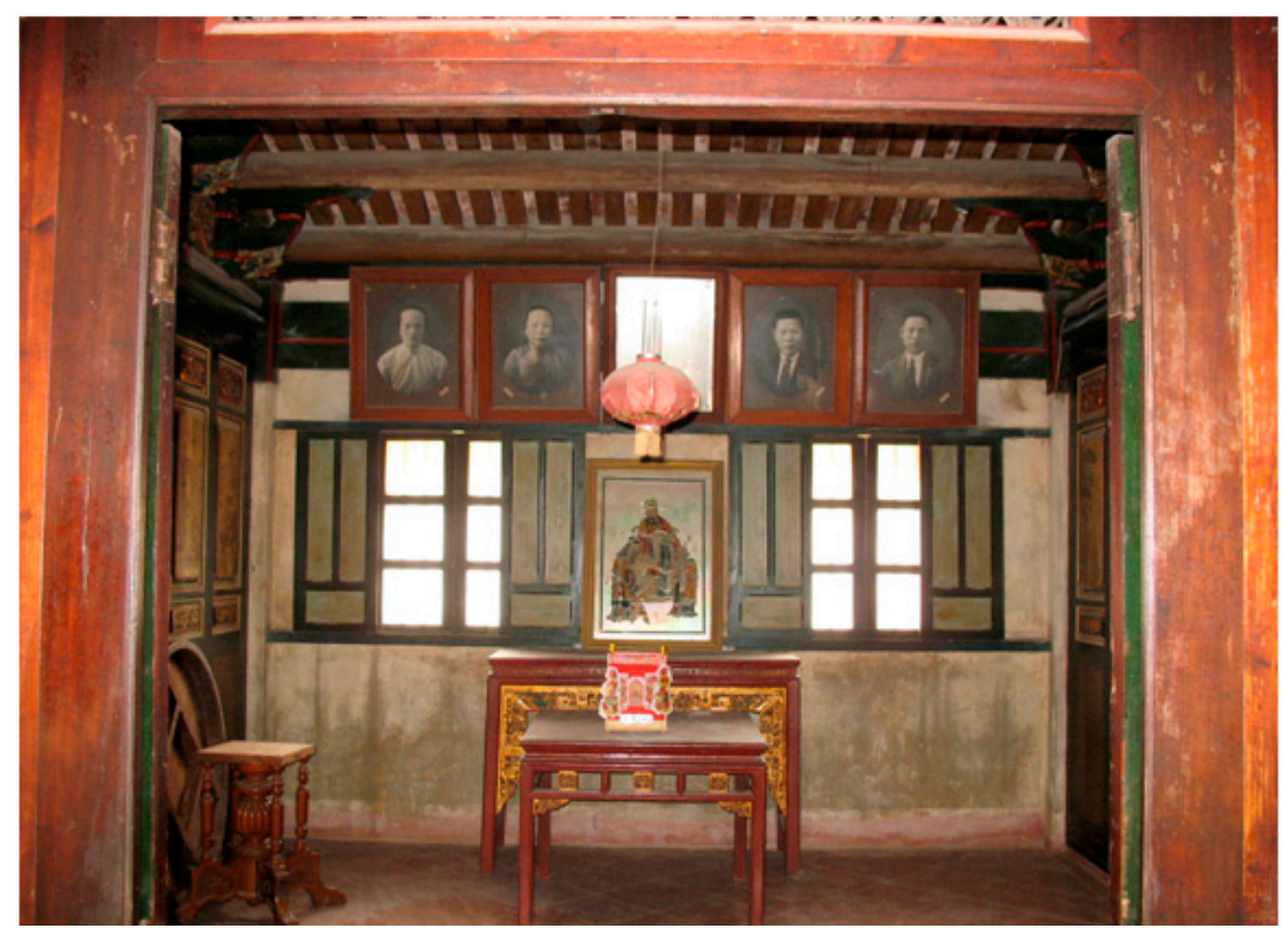

Fig. 6: Portrait of author's grandmother, great-grandmother, "great-grandfather," and grandfather, in ancestral room of the house in Zengkeng, Jinjing, Fujian, China.

From my visits to the village and interviews with people both in Manila and in Zengkeng, I learned that when he was ailing he spent his last few years in Zengkeng, bringing with him some relatives, including my great-grandmother, grandmother, and my eldest paternal aunt. But when Communists were taking over China, the rest of the family decided to return to Manila; they left him in Zengkeng, and let a family from another village to take care of him. He eventually died and his body and 
coffin were kept at the ancestral room in the house. My grandfather was supposed to return to give him proper burial rites, as was the custom. However, given the unstable conditions in China, my grandfather was unable to return, and soon died of an illness. Therefore, after a few years, our family instructed the caretakers to bury Yuanda. ${ }^{40}$

It was from my grandfather that I inherited the surname Chu. In my life, I have always had to explain to people, whenever they asked me whether I was related to another person with the same surname, that my real surname in Hokkien is Go (吕; pronounced "Wu" in Mandarin), and not Chu. When my grandfather came to the Philippines, he bought the landing certificate name or ICR (immigrant certificate of residence) of a certain Chu Ongco. ${ }^{41}$ Hence, "Chu Ongco" is the "tōa-jī miâ"42 ( 大字名; Hokkien derivation; dazi ming in Mandarin) of my grandfather, and also hence, the name I carry today. My cousins carry "Chuongco" as their last name but according to relatives, my late mother decided to simply use "Chu" instead of "Chuongco" in our birth certificates, to my father's chagrin.

The family genealogy lists eight sons. My grandfather married my grandmother, the daughter of Cai Nuo (蔡罢) from Keng Xi (坑西; also a village in Jinjing). She was born on 30 June 1901. Her full name in Hokkien is Chhòa lua. According to relatives, my grandfather died of kidney disease in 1956, at the age of fifty-eight years old (K. Tan). Based on the genealogy, my grandparents had eight sons, although they also had two daughters whose names were not listed. According to oral history, the first son died soon after being born. Distraught, my grandmother adopted a son to fill the emptiness she felt losing her first born. This adopted son became known as our first uncle. The third son also died as a child. My grandparents also adopted a little girl who later on became the wife of my first uncle. My father is listed as fifth in the genealogical line but since two sons born before him died, he was known as the "third uncle" to my cousins.

This is in essence a sketch of my family history. I am including it here to use it and my other research as bases for my discussion of the importance and relevance of researching Tsinoy families as well as of the other directions that such research can take. In the next section, I will elaborate on the relevant areas of reconstituting Tsinoy family histories.

\section{Relevance of Researching Tsinoy Families}

As mentioned earlier, researching one's family history can bring a great deal of satisfaction to the researcher as well as to the family members. On a personal level, constructing one's family history can give one a sense of pride and appreciation of the past, and a rootedness in the present. On a more societal level, the reconstitution of families, especially Tsinoy families, can lead us to broader questions that would help us understand better our nation's past. As Alfred McCoy argues, Philippine history can be understood through the "paradigm of . . families" (1). ${ }^{43}$ 
One aspect of Tsinoy family history that can contribute to a better understanding of our national history is the extensive network created by these itinerant families, especially those belonging to the merchant class, in the different regions around the Philippines as well as outside the country. During the latter part of the Spanish colonial era and the early decades of the American colonial period, the development of modes of transportation within the country and the region as well as the establishment of an export-oriented Philippine economy led to many Chinese participating in the economy as middle men, distributing goods within the country, the region, and the world. As seen in my research of my own family and those of others, Chinese traveled widely across the region-whether within the Philippines or within Southeast Asia/East Asia-seeking economic opportunities. By studying their travels we can begin to veer away from a Manila- and nationcentered history. Furthermore, studying Tsinoy families and how they survived the long separations or distances resulting from their members' itinerant lifestyle can also help us understand how families of Overseas Filipino Workers (OFW) are coping with new familial arrangements (Wickberg xxi-xxv).

Another aspect of Tsinoy family history that may have relevance to our country's social history is the domestic aspect of their lives. What do their familial practices tell us about the broader society in which they lived? For instance, among Chinese diasporic families, many practiced concubinage or bigamy/polygamy. Prominent Chinese merchants oftentimes had more than one wife and family. It was not unusual for them to keep a wife and family in China and another in the Philippines, and this practice seemed to be widely accepted within the community. But over time, such a practice became illegal or taboo, especially during the American colonial period in the Philippines. Hence, one can ask about who caused this change, the reasons for such change, and the implications for the country's culture and society then and now.

Yet another aspect of Tsinoy family history relevant to our country's history is its demonstration of the attempts of various dominant groups to control the Chinese and their family members, and at times the former's persecution or oppression of the latter. Tsinoy family histories can show not only how Chinese individuals suffered from discriminatory policies but also how they creatively negotiated the situation. This perspective can help us better understand how power relations operate in our society.

Finally, I would like to encourage researchers to also focus on the life histories of their female ancestors. Although throughout this essay "ancestor" is used to refer to both male and female individuals, oftentimes in family history projects the male ancestor is given preference over the female one. This may be due to pragmatic reasons (e.g., Chinese genealogies or zupus oftentimes just record male descendants). But this may also be due to the way traditional histories have been written-from a male perspective. But as we all know, women "hold up half the sky." As Gary Okihiro notes, in "recentering" women, we may extend the "interpretive" 
and "geographic" boundaries of what constitutes "Philippine" history. For instance, since many female ancestors have remained in China, conducting research on their lives would necessitate a transnational approach that would bring one's research outside the territorial boundaries of the Philippines. By focusing on women, our history is also reshaped since focusing on both men and women allows us to position "gender" - and not just "class" and "race" - as a "prominent social category in determining relations of power and trajectories of social change." A femalecentered history would also present us with new periodizations of our history that steers away from a chronology that focuses on events relevant not only to men but also to women (Okihiro 91-2).

What I have written in the previous paragraphs are merely suggestions on how one can frame one's family history project. In the end, the relevance of constituting one's family's history depends on individual and personal objectives and aims. This essay hopes to encourage Tsinoys to conduct family history research and provide some guidelines for undertaking such an endeavor. It also outlines some of the reasons for doing so. If it enables readers to even just start asking about the history of their families, then it will have taken a step closer to achieving its objectives. 


\section{Notes}

1. According to "Chinese Filipino," Austin Craig estimated that, as of 1915, a third of Filipinos living in Luzon had Chinese ancestry. Teresita Ang See states that many scholars (e.g., Otley Beyer) writing in the pre-World War II period would put the number at ten percent. However, she believes that due to the extent of intermarriages between "Filipino" and "Chinese after the second World War, the figure has gone up to at least twenty percent ("Re: translation.percentage"). Randy David writes that as much as fifty percent of Filipinos have Chinese ancestry.

2. Tsinoy comes from "Tsino" (Chinese) and "Pinoy" (colloquial term for "Filipino"). The term was coined by Kaisa Para sa Kaunlaran, Inc., a civic organization founded in 1987 by a group of young Chinese Filipinos to promote the integration of the Chinese into Filipino society. The term is used to refer to Filipinos who have Chinese ancestry and to Chinese who have been Filipinized. In this essay, I will be utilizing this term in the same way as Kaisa. Note, however, that in certain publications or periodicals, the word "Chinoy" is used instead.

3. Several works have been published explaining the importance of using microhistory for the study of human society. For example, István Szijártó gives four advantages of microhistory over macrohistory; namely, it is more "appealing to the general public, it is realistic, it conveys personal experience and whatever it has in its focus, the lines branching out from this reach very far" (211). John Brewer extols the usefulness of microhistory in the humanist agenda by providing human agency and the relegation of historical meaning to the transactions of everyday life (91). Carlo Ginzburg's groundbreaking book The Cheese and the Worms demonstrates to us how the lives of forgotten or marginalized individuals in history can point us toward a better understanding of the society in which those historical actors lived. In the same manner, Tsinoy life histories demonstrate to us how individuals through time deal with attempts of powerful groups to single out the "Chinese" as an "Other" in Philippine society. For different methods on writing microhistory, see the different essays in Brooks, DeCorse, and Walton; Levi (97-119); and Prins (120-56).

4. For example, in Cynthia Valdés' biography of Ongpin, the narrative about his life history is focused on his life and achievements in the Philippines. While there are chapters pertaining to the migration of the Chinese to the Philippines and on Chinese mestizos, the biography does not expound on the Chinese ancestors of Alfonso Ongpin.

5. A small number of excellent family histories with Chinese ancestry have been written in the last decade. One is by Josephine M.T. Khu and pertains to her family's ancestor Guillermo Cu Unjieng. Another book is by Raul Boncan and relates to his ancestors such as Mariano Limjap. Unfortunately, both works, while printed, are only available to family members. Biographies of FilipinoChinese tycoons have also been published, including Marites Khanser's work on John Gokongwei, Jr. and Wilfredo Villacorta's biography of Alfonso Yuchengco. 
6. For writers, family histories have provided rich content for their stories, novels, or plays. See the anthologies or books by Ong; D. Tan; See, Hau, and Sy; and Hau.

7. It is not within the scope of this paper to describe how to conduct oral histories; there are books and other publications on this topic that one can consult. The following are suggested works: Ritchie; Yow; Maynes, Pierce, and Laslett; and Charlton, Myers, and Sharpless. For those interested in doing oral histories with women, consult Yung's Unbound Feet and Chin's Doing What Had to be Done: The Life of Dora Yum Kim. Both are works on Asian American women. There are also websites that one can consult, including Moyer's Step-by-Step Guide to Oral History; Baylor University's Institute of Oral History; and the Oral History Association "Principles and Best Practices" site. I would like to thank Joyce Berkman for providing recommended resource guides.

Unfortunately, there are very few works that provide guidelines or methods on conducting oral history in the Philippines. An article written by Foronda points out that several institutions and universities in the Philippines had undertaken their own oral history projects. But due to lack of funds, most of these projects are individual-driven and unsuccessful ("Oral History" 20-1). It is best to follow, when possible and necessary, the guidelines provided by scholars in other countries, especially in the United States, in conducting oral history (see Foronda, "Oral History" 17).

8. Back in the late 1970s, Marcelino Foronda of De La Salle University initiated the Chinese in the Philippines Oral History Project (CPOHP). His students interviewed different individuals and the transcripts of the interviews were kept in Foronda's personal library. Unfortunately, Foronda died in 1997. For information regarding the CPOHP, see Foronda, Kasaysayan 60-7.

9. However, among "Chinese" families, the Chinese surname is still known and used within the "Chinese" context.

10. One source of documents that can yield information regarding certain Chinese individuals, especially those belonging to the lower-income bracket, are the Asuntos Criminales (Criminal Matters) and Asuntos Civiles (Civil Matters). This is not to insinuate that only poorer Chinese committed or were involved in crimes or disputes, but merely to say that such documents are one of the few available sources of substantial information about the Chinese.

11. The Church of Jesus Christ of the Latter-day Saints microfilmed many of the records of the National Archives of the Philippines and the collection of other repositories, including the Archdiocese of Manila. Use of these microfilm reels can be requested through the various Family History Centers located all over the Philippines. Furthermore, Kaisa Para Sa Kaunlaran, Inc., in cooperation with the Institute of Modern History in Taiwan, has managed to microfilm a total of 1.4 million documents pertaining to the Chinese in the Philippines during the Spanish colonial period. These documents produced a total of 720 microfilm reels. The original copies of the reels are located at the Institute of Modern History but duplicate copies can be found at the National Archives of the Philippines ("Cultural/Educational Activities"). 
12. Such records were not restricted when I did research at the Archives of the Archdiocese of Manila from 1997-2001. However, one way to access these records is to use the website of The Church of Jesus Christ of the Latter-day Saints (see FamilySearch).

13. The FamilySearch website lists holdings from the Archdiocese of LingayenDagupan and the Diocese of San Fernando de La Union. In Cebu, it was believed that records and other documentary sources were destroyed during World War II. However, recently the Archdiocese of Cebu built a museum, and there is reason to believe that not all the documents have been destroyed, and might be found or stored in the archbishop's palace and convent (M. Cullinane).

14. For more information regarding the library's holdings, see Chinben See Memorial Library.

15. It is also recommended to visit the websites of these institutions or libraries and check their catalogs.

16. For more information regarding the holdings of the Spanish Archives, see Menegon.

17. For a general list of catalogues and overview of such websites, see Chao 308-13.

18. For information regarding the holdings of these libraries, see Center for AsiaPacific and Institute of Modern History, respectively.

19. Examples of Chinese publications include Zhou Nanjing's Shijie huaqiao huaren cidian (世界華僑華人詞典, Dictionary of Overseas Chinese), and the Jinjiang huaqiao zhi (晋江華僑志, Gazetteer of Overseas Chinese from Jinjiang). These books may also be available at the Chinben See Memorial Library.

20. This paper is an updated version of an earlier work by Ang See, entitled "Research on the Chinese in the Philippines."

21. Wickberg's book remains the seminal work on the history of the Chinese and Chinese mestizos in the Philippines during the Spanish colonial period, especially from 1850 to 1898 . It is rich in historical details and provides an excellent overview of the political, economic, and social structures of the time pertaining to the Chinese and Chinese mestizos. The drawback is that the book, using earlier sociological paradigms on ethnicity, tends to portray ethnic identities in binarist terms. Felix's two-volume work contains materials that are not otherwise found in Wickberg's book, especially during the earlier Spanish colonial period. Some essays are more academic, allowing other scholars to gain not only more knowledge and information about possible sources for research but also a broader understanding of the history of Philippine society at the time. The other contributions to the anthology are a mixture of translations and less intellectually rigorous writings on the subject matter.

22. Both works steer clear of the usual periodization found in previous works in order to emphasize the continuities of the late Spanish and early American colonial periods. In doing so, the studies also demonstrate the differences and similarities of the two empires. More importantly, the two studies looks into how individuals, from Chinese merchants (in the case of Wilson) to Chinese mestizos and mestizas (in the case of $\mathrm{Chu}$ ) negotiated the attempts of dominant groups to control them by engaging in flexible, border-crossing, or transnational practices. 
Focused on "elite" families, the two works point to the need of more studies on lower-income Chinese individuals and families.

23. A. Tan's Chinese in the Philippines, 1898-1935 takes off where Wickberg's end in terms of periodization and does an excellent job in describing the different "Chinese" organizations, newspapers, schools, and the broader political picture in order to explain how the "Chinese" in the Philippines developed their sense of nationalism toward China. Wong also does a splendid job in explaining how the Chinese during the American colonial period prospered in the first three decades of the twentieth century, and the types of industries and commerce they entered and monopolized as a result of government policy and their own entrepreneurship. But as indicated in the Introduction, these periodizations are based on metanarratives that only serve the nationalist agenda and hence may exclude other important facets of Philippine history.

24. This work is so far the only work that provides an overview of the history of the Chinese during the Japanese occupation of the Philippines. Yet there is still so much that needs to be written that hopefully more studies can be made focusing on this period.

25. The different articles found in these volumes pertain to different topics ranging from economic, social, to political issues facing the Tsinoy community postWorld War II. The analyses of these essays are mostly from the perspective of integrating the Chinese into Filipino society.

26. A caveat about this work: the historical period only spans from the 16th century till the 1940s.

27. I would like to thank Caroline Hau for pointing this out to me.

28. Jill Lepore, noted Harvard University historian, was quoted in Francesca Mari's

"The Microhistorian" as saying that biography is "largely founded on a belief in the singularity and significance of an individual's life and his contribution to history," while "microhistory" treats a singular person's life in its "exemplariness," i.e., on how it "serve as an allegory for broader issues affecting the culture as a whole."

29. The magazine of Kaisa Para Sa Kaunlaran, Inc., named Tulay, has also published a series of articles under a column "Relative Finder." A contributor, named Eduardo Chan de la Cruz, Jr., described his experiences in finding relatives in China. It is both an inspiring and poignant tale of family history, involving poverty, wars, and happy reunions. See de la Cruz.

3o. See, for example, In Memory of Madame The Siu Yong Limpe. It is a wonderful tribute to the matriarch of the Limpe family, complete with photos and descriptions of her achievements, and published both in Chinese and English. The biography is also laudable for its focus on a female individual. As with other "grey" literature, this biography is not available in bookstores, but a copy can be found at the Chinben See Memorial Library.

31. Hokkien is also known in Mandarin as "Minnan hua” (閩南話). It might also be helpful to also use a Hokkien dictionary because some terms in Hokkien do not appear in Mandarin or putonghua (普通話) dictionaries.

32. See, for example, Liangqian nian Zhongxi li zhuanhuan. 
33. Zengkeng is a small and sleepy farming village located two hours away from Xiamen. A walk around the village shows that most of the houses there are made of bricks, except that of my great-grandfather's, which is made of concrete. Many of the families in this village have a long history of emigration to Southeast Asia. A study of over 30,00o tombstones in Manila's Chinese Cemetery shows that 66 percent of those buried there were from Jinjiang county (Chu 29).

34. Ludong was the fifth son of Wurong (武榮) who worked for the Board of Personnel. He moved to Jinjing (金井) in 1385 from Huanglong, in the region of Jiangnan (黃龍江南).

35. For the rest of my account of my family's history, the dates are based on the Chinese lunar calendar. To find the equivalent date on the Gregorian calendar, refer to the website Liangqian nian. In using this site, for example, the birthdate of my great-grandfather is 1 October.

36. Records indicate that she was born between 7:00 and 9:00 a.m.

37. She died between 5:00 and 7:00 p.m.

38. Like that of his brothers, Binglin's date of death is not recorded in the genealogy. But based on Yuanda's account, he probably died during the Japanese occupation in the Philippines or a few years after that, i.e., somewhere between 1942 and 1950.

39. I am not certain whether this is a person's or a place name.

40. His mausoleum (see photo below) stood in the field in front of the house that he built. But in the late 20oos, the government destroyed it in order to build a new road. His and my great-grandmother's remains were relocated.

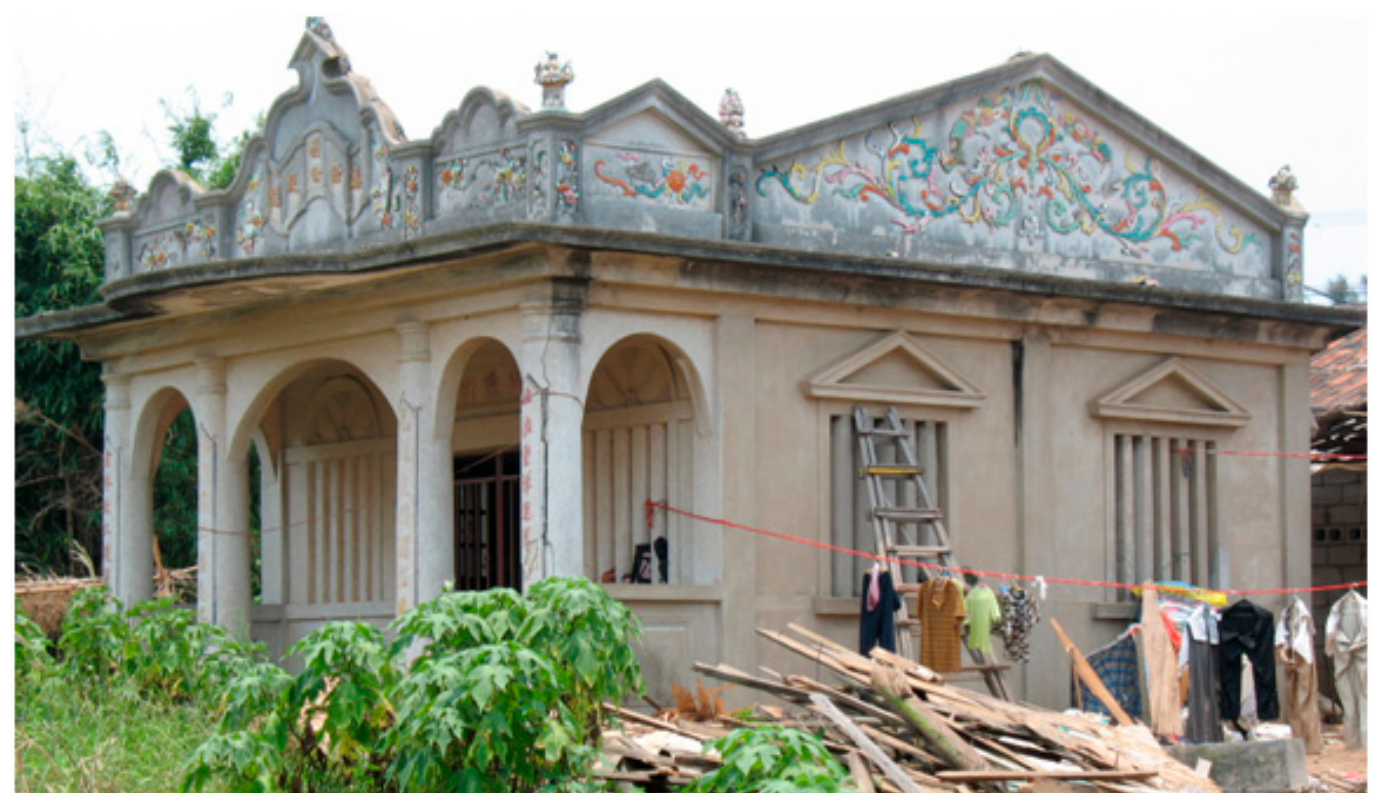

41. I found in the Archives of the Archdiocese of Manila a baptismal record dated 18 September 1868 belonging to a Chu Ongco from the town of Cainta in the 
district of Moron (sic). Whether this was the person from whom my grandfather bought the ICR needs to be ascertained (Chu Ongco Baptismal Application).

42. Because these certificates were so large and the script therefore as large, they were called tōa-jī which literally means "big character." Hence, the surname adopted by an individual who bought such certificates is referred to as the person's "big character" name.

43. Specifically, McCoy refers to elite families (e.g., the Cojuangcos, Aquinos, Macapagals, and the Marcoses) who have played a long and continuous role in the country's economy and politics. He writes that in countries like the Philippines and those in Latin America, such as Mexico and Brazil, writing or focusing on elite families that influence or affect so much of their countries' political, economic, and social life can lead "to discover new dimensions in (these countries') national histories" (5).

\section{Works Cited}

A Modern Chinese-English Dictionary. Oxford UP, 1990. Print.

Archdiocesan Archives. The Roman Catholic Archdiocese of Manila, n.d. Web. 16 May 2013.

Boncan, Raul L. House of Limjap, Vol. 1., 1997. TS. Collection of Richard T. Chu, Northampton, MA, USA.

--.. House of Limjap, Vol. 2, 20oo. TS. Collection of Richard T. Chu, Northampton, MA, USA.

Brewer, John. "Microhistory and the Histories of Everyday Life." Cultural and Social History 7.1 (2010): 87-109. Print.

Brooks, James, Christopher R. DeCorse, and John Walton. Small Worlds: Methods, Meaning, and Narrative in Microhistory. Santa Fe: School for Advanced Research, 2008. Print.

Center for Asia-Pacific Area Studies, RCHSS. Academia Sinica, 16 May 2013. Web. 16 May 2013.

Chao, Sheau-yueh J. "Documentation and Resource Sharing on Chinese Genealogical Resources: Opportunities and Challenges." Chinese Overseas: Migration, Research and Documentation. Eds. Tan Chee-Beng, Colin Storey, and Julia Zimmerman. Hong Kong: Chinese UP, 2007. 297-320. Print.

Charlton, Thomas, Lois E. Myers, and Rebecca Sharpless. Handbook of Oral History. 2006. Lanham: AltaMira, 2008. Print.

Chia, Lucille. "The Butcher, the Baker, and the Carpenter: Chinese Sojourners in the Spanish Philippines and their Impact on Southern Fujian (Sixteenth-Eighteenth Centuries." Journal of the Economic and Social History of the Orient 49.4 (2006): 509-34. Print.

Chin, Soo-Young. Doing What Had to be Done: The Life Narrative of Dora Yum Kim. Philadelphia: Temple UP, 1999. Print.

Chinben See Memorial Library. Kaisa Para Sa Kaunlaran, n.d. Web. 16 May 2013.

"Chinese Filipino." Wikipedia, 16 May 2013. Web. 16 May 2013. 
Chu Ongco Baptismal Application. Solicitudes de Chinos sobre Bautismos, 34.D.11 folder 11. Archives of the Archdiocese of Manila. MS. Collection of Richard T. Chu, Northampton, MA, USA.

$\mathrm{Chu}$, Richard T. Chinese and Chinese Mestizos of Manila: Family, Identity, and Culture, 186os-1930s. Leiden and Boston: Brill, 2010. Pasig City: Anvil, 2012. Print.

Cullinane, Michael. "Re: Query re Cebu Archdiocesan Archives." Message to the author, 6 May 2013. E-mail.

"Cultural/Educational Activities." Kaisa Para Sa Kaunlaran, n.d. Web. 16 May 2013. de la Cruz, Edgardo Chan Jr. "Relative Finder: The Missing Tomb." Tulay 25.11 (4-17 December 2012): n.p. Web. 15 May 2013.

David, Randy. "The Call to Boycott Chinese Products." Philippine Daily Inquirer, 19 Jul. 2012. Web. 11 May 2013.

FamilySearch. The Church of Jesus Christ of Latter-day Saints, 2013. Web. 15 May 2013.

Felix, Alfonso Jr., ed. The Chinese in the Philippines: 1570-1770. Vol. 1. Manila:

Solidaridad, 1966. Print.

---, ed. The Chinese in the Philippines: 1770-1898. Vol. 2. Manila: Solidaridad, 1969. Print.

Foronda, Marcelino A. "Oral History in the Philippines: Trends and Prospects." The International Journal of Oral History 2.1 (1981): 13-25. Print.

--. Kasaysayan: Studies on Local and Oral History. Manila: De La Salle UP, 1991. Print.

Fung, Cornelia L. Beneath the Banyan Tree: My Family Chronicles. Hong Kong: CBL Fung, 2009. Print.

GenForum. Ancestry.com, n.d. Web. 16 May 2013.

Ginzburg, Carlo. The Cheese and the Worms: The Cosmos of a Sixteenth-Century Miller. Trans. John Tedeschi and Anne C. Tedeschi. Baltimore: Johns Hopkins UP, 1992. Print.

Gooch, Anthony and Angel Garcia de Paredes. Cassell's Spanish-English, EnglishSpanish Dictionary. London: Cassell, 1978. Print.

Hau, Caroline S., ed. Intsik: An Anthology of Chinese Filipino Writing. Pasig: Anvil, 200o. Print.

Huang Zisheng (黄滋生) and He Sibing (何思兵). Feilubin huaqiao shi (菲律宾華僑史, The History of the Chinese in the Philippines). Guangdong: Guangdong gaodeng jiaowu chuban she (廣東高等教育出版社), 1987. Print.

Huaqiao huaren baike quanguo shu (華僑華人百科全國書, Encyclopedia of Chinese Overseas: Volume of Academic Works). Beijing: Zhongguo huaqiao chubanshe (中國 華僑出版社, Overseas Chinese Publishing House), 20oo. Print.

In Memory of Madame Teh Siu Yong Limpe: A pioneer in Fil-Chinese Women's Equal Rights Movement. Lin Dai Xiu Rong nu shi jinian ji (林戴秀容女士紀念集). N.p, n.d. TS. Chinben See Memorial Library, Kaisa Heritage Center, Manila, Philippines.

Institute for Oral History. Baylor U, n.d. Web. 18 May 2013.

Institute of Modern History. Academia Sinica, 2010. Web. 16 May 2013.

Kaisa Research Center and Data Bank. Kaisa Para Sa Kaunlaran, n.d. Web. 15 May 2013.

Khanser, Marites A. John Gokongwei Jr.: The Path of Entrepreneurship. Quezon City:

Ateneo de Manila UP, 2007. Print.

Khu, Josephine M.T. The Life and Family of Guillermo A. Cu Unjieng. Manila: Liren Culture Foundation, 2008. Print. 
Liangqian nian Zhongxi li zhuanhuan. Academia Sinica Computing Center. Web. 18 May 2013.

Jinjiang huaqiao zhi (晉江華僑志, Gazetteer of Overseas Chinese from Jinjiang), 1994. Shanghai: Shanghai renmin chuban she (上海人民出版社). Print.

Lawphil Project. Arrelano Law Foundation, n.d. Web. 16 May 2013.

Levi, Giovanni. "On Microhistory." New Perspectives on Historical Writing. Ed. Peter Burke. 2nd ed. University Park: Pennsylvania State UP, 2001. 97-119. Print.

Li Tianxi. Jinjiang huaqiao yishi (至江華僑軼事, Anecdotes of Chinese Overseas from Jinjiang), 2002. Xiamen: Xiamen daxue chuban she. Print.

Lim, Rodrigo. Who's Who in the Philippines. Chinese edition. Manila: $\mathrm{U}$ of the Philippines P, 1930. Print.

Mari, Francesca. "The Microhistorian." Dissent: A Quarterly of Politics and Culture (2013). Web. 19 June 2013.

Mathews, Robert Henry. Mathews' Chinese-English Dictionary. Cambridge: Harvard UP, 1963. Print.

Maynes, Mary Jo, Jennifer L. Pierce, and Barbara Laslett. Telling Stories: The Use of Personal Narratives in the Social Sciences and History. Ithaca: Cornell UP, 2008. Print.

McCoy, Alfred W., ed. An Anarchy of Families: State and Family in the Philippines. Madison: U of Wisconsin, Center for Southeast Asian Studies, 1993. Print.

Menegon, Eugenio. "A Note on the Archivo de la Provincia del Santo Rosario in Avila, Spain." Sino-Western Cultural Relations Journal, XVI (1994): 73-75. Print.

Ming Feng (鳴鳳). “Chongxiu Zengkeng xian zongpu xu” (重修澄坑鄉宗譜序) (Preface to the Revision of the Zengkeng Family Genealogy). Wushi jiapu (吳氏家譜) (Wu Surname Family Genealogy). 1934. MS. Collection of Richard T. Chu, Northampton, MA, USA.

Moyer, Judith. Step-by-Step Guide to Oral History. 1999. Web. 18 May 2013.

National Archives of the Philippines. National Archives of the Philippines, 2013. Web. 15 May 2013.

Okihiro, Gary. Margins and Mainstreams: Asians in American History and Culture. Seattle: U of Washington P, 1994. Print.

Omohundro, John T. Chinese Merchant Families in Iloilo. Quezon City: Ateneo de Manila UP, 1981. Print.

Ong, Charlson. Men of the East and Other Stories. Manila: Kalikasan, 1990. Print.

--. Woman of Am-Kaw and Other Stories. Pasig: Anvil, 1992. Print.

"Principles and Best Practices." Oral History Association, October 2009. Web. 18 May 2013.

Prins, Gwyn. "Oral History." New Perspectives on Historical Writing. Ed. Peter Burke. 2nd ed. University Park: The Pennsylvania State UP, 2001. 120-56. Print.

Quanzhou shi huaqiao zhi (泉州市華僑, Gazetteer of Overseas Chinese from Quanzhou). Beijing: Zhongguo shehui chuban she (中国社会出版社), 1996. Print.

Research Center for Humanities and Social Sciences. Academia Sinica, n.d. Web. 16 May 2013.

Retana, Wenceslao E. Diccionario de Filipinismos. Madrid: La Real Academia Espanola, 1921. Print.

Kritika Kultura 21/22 (2013/2014): -029

(c) Ateneo de Manila University

<http://kritikakultura.ateneo.net> 
Ritchie, Donald. Doing Oral History: A Practical Guide. Oxford: Oxford UP, 2003. Print. Rizal, José. Historical Events of the Philippine Islands. Manila: José Rizal National Centennial Commission, 1962. Print.

Santos, Ruperto. Archdiocesan Archives of Manila: A Catalogue of Archival Documents, Testaments, and Holdings. Intramuros, Manila: Roman Catholic Archbishop of Manila, 1994. Print.

See, Chinben and Teresita Ang See. Bibliography of Works on the Chinese in the Philippines, 1990. Print.

See, Teresita. The Chinese in the Philippines. 3 vols. Manila: Kaisa Para Sa Kaunlaran, 1990, 1997, 2004. Print.

--.. "Research on the Chinese in the Philippines in the Last Two Decades." Chenfeng boliang yicanghai (《乘風破浪济沧海》, 华社研究中心 20 周年紀念特刊; Riding the Wind and Waves, Bridging the Deep Blues Seas). Ed. Voon Phin Keong (文平 强).Kuala Lumpur, Malaysia: Center for Malaysian Studies (華社研究中心),2005. 088-097. Print.

--. "Recent Studies, Research, Publications and Source Materials on the Chinese in the Philippines." The Ninth International Conference on the Philippines. Michigan State University, 28-30 Oct. 2012. Conference Presentation.

--.. "Re: translation.percentage." Message to the author, 16 May 2013. E-mail.

See, Teresita, Caroline S. Hau, and Joaquin Sy, eds. Voices; Mga Tinig: The Best of Tulay. Manila: Kaisa Para Sa Kaunlaran, 1997. Print.

Sidharta, Myra. "Collecting 'Grey Literature' from Indonesia." Chinese Overseas: Migration, Research and Documentation. Eds. Tan Chee-Beng, Colin Storey, and Julia Zimmerman. Hong Kong: Chinese UP, 2007. 85-102. Print.

Szijártó, István. "Four Arguments for Microhistory" Rethinking History 6.2 (2002): 20915. Print.

Taiwu xianding zidian (台語線頂字典) Web. 18 May 2013. <210.240.194.97/TG/jitian/ tgjt.asp>.

Tan, Antonio. The Chinese in the Philippines, 1898-1935: A Study of Their National Awakening. Quezon City: Garcia Pub., 1972. Print.

--. The Chinese in the Philippines During the Japanese Occupation, 1942-1945. Quezon City: U of the Philippines P, 1981. Print.

Tan, Debbie Ann L. Modern Tsinoy Plays: Time Waits and Other Plays. Manila: Bookmark, 2010. Print.

Tan, Katherine C. "Re: More questions and latest draft." Message to the author, 15 March 2012. E-mail.

Valdés, Cynthia O. At my Grandfather's Knee: A Portrait of Alfonso T. Ongpin. Muntinlupa City: Mission View, 2006. Print.

Villacorta, Wilfredo V. Alfonso T. Yuchengco: A Lifetime of Integrity. Manila: De La Salle UP, 2003. Print.

Wickberg, Edgar B. The Chinese in Philippine Life, 1850-1898. New Haven: Yale University Press, 1965. Quezon City: Ateneo de Manila UP, 20oo. Print.

--.. Introduction. Chinese Merchants of Binondo in the Nineteenth Century. By Richard T. Chu. Manila: U of Santo Tomás P, 2010. ix-xxvi. Print. 
Wolters, O.W. History, Culture, and Region in Southeast Asian Perspectives. Singapore: Institute of Southeast Asian Studies, 1982. Print.

Wilson, Andrew. Ambition and Identity: China and the Chinese in the Colonial Philippines, 1880-1916. Honolulu: U of Hawaii P, 2004. Print.

Wu Yuanda. Personal testament. 15 March 1947. TS. Collection of Richard T. Chu, Northampton, MA, USA.

Wushi jiapu (吳氏家譜) (Wu Surname Family Genealogy). MS. Collection of Richard T. Chu, Northampton, MA, USA.

Xiamen huaqiao zhi (厦門華僑志, Xiamen Overseas Chinese Gazetteer). Xiamen: Lujiang chuban she (笉江出版社), 1991. Print.

Yow, Valerie Raleigh. Recording Oral History: A Guide for the Humanities and Social

Sciences. Walnut Creek: AltaMira, 2005. Print.

Yung, Judy. Unbound Feet: A Social History of Chinese Women in San Francisco. 1995. Berkeley: U of California P, 1999. Print.

Zhou, Nanjing. Shijie huaqiao huaren cidian (世界華僑華人詞典, Dictionary of Overseas Chinese). Beijing: Beijing daxue chuban she (北京大學出版社), 1993. Print. Zhuang Weiji (庄為玑) and Zheng Shanyu (鄭山玉). Quanzhou pudie huaqiao shiliao yanjiu (泉州譜牒華僑史與研究, The History and Study of the Genealogies of Quanzhou Overseas Chinese). Zhongguo huaqiao chubanshe. Vol. 1 and 2 (上下). 1994. Print. 